Assistant of the Foreign Philology Department (Kyiv National University of Culture and Art) Julialeo1619@gmail.com ORCID: 0000-0002-7935-0382

\title{
COMMUNICATIVE APPROACH IN TEACHING ITALIAN AS A SECOND FOREIGN LANGUAGE
}

The article is dedicated to the theoretical and methodical investigation of the specific of teaching Italian as a second foreign language and improving their level of the professional communicative competence in class. The

perspective of using communicative approach is released as well as the requirements for their choice. It is mentioned that small talks are essential resource in time of new terms learning and that in general they improve the level of the translators' professional communicative preparation.

The specific of the contemporary communicative preparation in teaching Italian is caused by integrational processes in our society, globalization and access to the information worldwide web, the necessity in highly competent specialists in the translation field, tourism and translation. The requirement of our time is to change the approach of our educational paradigm giving priority to the communicative preparation, which points out

the main aim of the teaching process at the university level. The experimentally proved system of the

communicative approach in teaching Italian as a second foreign language consists of three main stages: preparation, main body and analyses. The quintessential part of the technology is the formation of imprinting in time of learning new words and being ready to write the individual creative essays. Communicative approach is directed on the foreign communicative competence formation of the future philologists.

Key words: communicative approach, teaching Italian, second foreign language, professional communicative preparation, future philologists, creative writing, communicative competence, communicative preparation.

\section{Introduction.}

The aim of the article is to reveal theoretical and methodical foundations of the communicative approach formation of future philologists by means of teaching Italian as a second foreign language.

According to the set aim, the following tasks can be determined:

1. To distinguish the peculiarities of the foreign language communicative competence of the future philologists on the basis of the professional communicative training analysis, done by means of the creative writing.

2. To form the conception and to give grounds to the theoretical and methodological means of the professional communicative training of the future philologists.

3. To describe the pedagogical system of the professional communicative training of the future philologists by means of the small talks.

4. To create the author's technology, as an element of the future philologists pedagogical training, dealing with the communicative approach and author's works.

5. To determine the diagnostic figures of the formation level of the future philologists' competence in the poetry and prose.

6. To do the experimental check of the pedagogical system efficiency of the communicative approach training by means of the creative writing and small talks.

Communicative approach intends to activate the processes of learning and language acquisition in the four linguistic skills (listening, speaking, reading and writing). Such teaching emphasizes the importance of interaction between students and the teacher. Though this approach it is created a learning path focusing on the unique characteristics of each student and on the development of effective and useful language teaching, communication skills. It is proved that such approach is one of the most effective in teaching Italian as a second foreign language. Students don't learn mechanically and theoretically; on the contrary, most of the class is dedicated and oriented on practice, so students could improve their language skills and feel confident and ready to face any real life communication challenge.

Following the acquisition learning hypotheses of the communicative teaching it is necessary to explore the need to act on two levels in order to develop language competencies: acquisition, (which develops our subconscious level) and learning (which develops our conscious level). The teaching of Italian language as a second foreign takes into consideration Gardner's Theory of multiple intelligences and suggestopedia meaning that teachers present activities in class in order to accommodate different learning styles. Today in contrast to traditional methods that are set to be not effective in certain academic syllabi, linguists agree that we can distinguish between a learning phase (conscious phase) and acquisition's one (subconscious phase) in the study of a foreign language, in our case Italian language as a second foreign language.

Research methods.

The following methods were used to dispose the given tasks: 
- theoretical: critical analysis of the issue on the basis of works on philosophy, psychology, theory of translation, pedagogy and foreign language teaching methods; theoretical generalization of the Ukrainian high educative institutions work and experience; empiric material synthesis, its classification, generalization and rearranging to give the grounds of the conceptual issues and the pedagogical system of the future philologists communicative approach training by means of the creative translation;

- empiric: poll, discussions with students, post-graduates, teachers, linguists, methodologists, their interviewing, direct and indirect pedagogical observation of the educational process and analysis of the Italian classes, documentation, plans, practical course and theory of translation programs studying; predicting (expert estimation method, experimental tasks) to determine the professional communicative competence degree of the future philologists; its formation dynamics, training peculiarities of the students-philologists to their professional activity; pedagogical experiment to check given training system efficiency; rating and self-rating methods.

Discussion.

The system of professional communicative approach in teaching Italian as a second foreign language was worked out and scientifically approved in, methodological and methodical levels, as its main system creative components was analyzed (motivational-creative, cognitive-creative, creative-objective, verbal-productive and emotional-creative) for effectiveness. It has been based on the assertion of the system of competent, individualcreative, communicative, thesaurus, synergy, acmeological and intersubject approaches. The main attention at educational establishments should be paid to the specific techniques and teaching activity aspects directed on the creative disposition of future philologists' development. The conceptual grounds of the system are given to the idea of professional-creative students' inborn qualities, unleashing and developing them. The project involves theoretical-methodological bases, reflects the unity of theoretical and methodical preparation, and structural and functional components connection. It is grounded in the structure, defined by the criteria and indicators of forwardness, and has experimentally proved the validity of the communicative approach in teaching Italian as a second foreign language in Ukraine. It is a developed structure-functional model which reflects the interconnection and interaction of theoretical and practical components for preparation; the conditions of preparation; principles of preparation; the content of preparation; the technology of preparation; pedagogical conditions; stages of preparation: beginning stage (diagnostic reproductive), basic stage (scientific creative), and final stage (productive creative); criteria; levels of international communicative competence formation; and preparation results.

By analyzing the problems of teaching Italian as a second foreign language by means of the communicative approach there were discovered the specifics of the process of foreign communicative competence formation of future philologists, in developing the concept and proved theoretical-methodological principles of professional communicative preparation. It is modelled in the pedagogical system of professional communicative preparation of future philologists by means of communicative approach, developing the authors' methodology of future philologists' preparation for speaking Italian fluently and personal creative writing. It is provided with experimental quality control of the system of professional communicative preparation of future philologists by means of communicative approach and proved that the following project is of great interest for the teachers and students of Ukraine which is going to raise the level of Italian in general and influences the foreign communicative competence.

In our work, the professional communicative training of the future philologist is the theoretical and practical education in the higher education institutions, providing the author's special educative program by means of communicative approach, referring to the communicative competence formation, which is necessary for the successful professional activity.

Pedagogical system of the future philologist professional communicative competence, based on the communicative approach, is a type of education, specific range of aims, tasks, principles, means, content, creative-innovative forms (methods, means), communicative strategies and criteria of the designed model efficiency rating. All the components ties are described on the scheme 1 . 


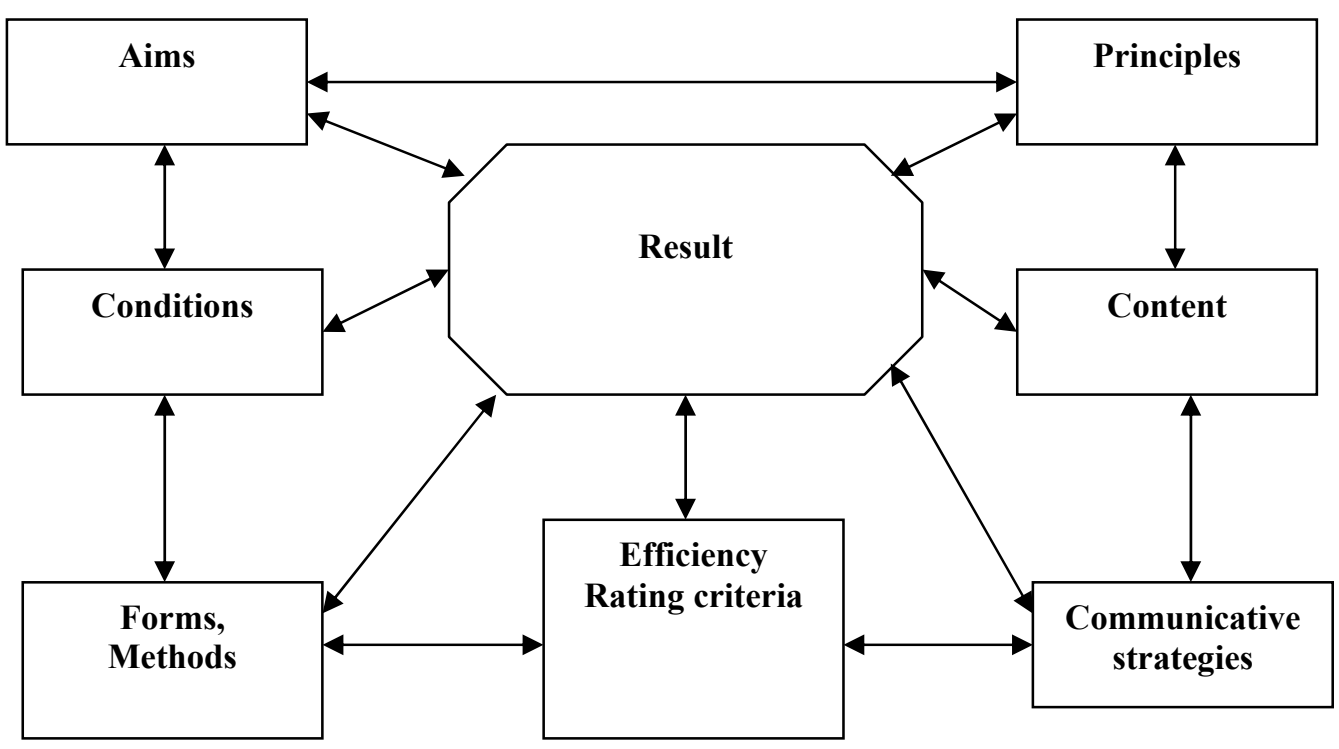

\section{Scheme 1. Components ties of the pedagogical model based on the communicative approach in teaching Italian as a second foreign language}

The aim of the designed pedagogical system is to determine the effective creative means, methods and forms of the educative activity, which will help to form the professional communicative competence, to increase the educational quality in the higher education institutions at the foreign language departments, especially in time of teaching Italian as a foreign language. All these will help students to adopt to their professional activity conditions. Thus, the aim of our work is to increase the conscious guidance of the thinking process and at the same time, to intensify the intelligent component of the students' activity.

The pedagogical system contains the scientific-methodological knowledge, pedagogical and methodological creativity notions of the teacher of the foreign languages, its specificity and conformity, professional skills, the foreign language, communicative strategies development, built on the communicative approach among the future philologists.

Analysis of the high school educational programs, dealing with the foreign language teaching preceded the content development, which showed little interest to the communicative competence of the future teacher and interpreter, different aspects of the creative translation study and its application within the practical Italian teaching course.

The important condition of the creation, development and functioning of the system is to determine the basic principles of the content, methods and forms of the educational process organization.

General and specific principles of the given pedagogical system are creativity, subjective dominant, informative redundancy prevention, educational process personification, future professional activity orientation, cognitive graphics, communicativeness, orientation on speaking, priority of creativity among the reproductive, mimetic principles and spontaneous speaking.

Conclusions.

The following conclusions can be made according to the given result generalization: peculiarities of the foreign communicative competence of the future philologists, based on the psychological-pedagogical and linguistic researches of the professional communicative training by means of the communicative approach in teaching Italian. Here it's necessary to take into account the students individual characteristic features, effected the quality of the educational program understanding and the creative works writing process, personal creative approach to the new thesaurus of the Italian language learning, using the individual and creative tasks, specifying the students communicative strategies.

The modern theoretical issues investigation gave the opportunity to determine the main researching measures of the cognitive graphics, creativity, subjective dominant, education process individualization, future profession orientation, communicativeness, spontaneous speaking within the future philologists professional communicative training by means of communicative approach. Systematic, competent, creative, communicative, thesaurus, synergetic, interdisciplinary approaches to the process of the professional communicative competence formation, as a complete individual characteristic feature, providing the successful speaking process was theoretically grounded.

Orientation of the modern education process to the competence approach of the professional experts training determined the creative competence as one of the main premises of the future philologists' communicative competence by means of the communicative approach. 
The experimental technology of the future philologists' professional communicative training by means of communicative approach is described through the complex of the communicative tasks and exercises on the eclectic and heuristic foreign language materials and manuals for the communicative approach.

Pedagogical system of the future philologists communicative training in their professional activity combines theoretical-methodological basis, shows the unity of the students' theoretical, methodological and informational training, coordination of the structural and functional components. Foreign communicative competence formation of the future philologists is a complex and dynamic process.

The result of the pedagogical system is the foreign communicative competence formation of the future philologists. The main components, influenced on the professional communicative competence forming of the future philologists are the methodological approaches to the educational process, the future philologist model; ready to use the creative kind of translation, basic components and preparation steps, conditions, training methods.

The criteria of the foreign communicative competence levels of the future philologists were formed with the poetic and prose speaking text organization. Due to the given results, the criteria (creativity, communicative strategies and tactics, the cognitive activity content, communicative strategies learning system, analysis depth, ideas originality, thinking flexibility, new lexics learning, views and conclusions independency, research motivation, communicative activity prosperity, objective rating) and the professional communicative competence of the future philologists by means of communicative approach (low, medium, high) were concretized.

According to the practical feature of the educational process content, the codewords of the professional communicative competence of the future philologists were formed. The rating criteria of the professional communicative competence of the future philologists were determined. The 100 score scale of the professional communicative competence levels reflects the knowledge, skills and other categories.

The given research doesn't embrace all the aspects, dealing with the teaching Italian as a second foreign language by means of communicative competence formation. The new problematic issues of the scientific research needed to be further developed could be mentioned in the possible intensification ways of the Italian language teaching among the students, creative methodology extrapolation on other foreign languages, and the system of the foreign communicative strategies formation.

\section{REFERENCES}

1. Barnstone Willis The Poetics of Translation: History. Theory. Practice/ Barnstone Willis. - London: Yale University Press, 1993. -302 p.

2. Berube Michael The Employment of English : Theory, Jobs, and the Future of Literary Studies / Michael Berube. New York : NYUP, 1998

3. Bialystok E. Communication Strategies: A Psychological Analysis of Second Language Use/ E. Bialystok. Oxford : Blackwell, 1990.

4. Carolyn P. Sobel The Cognitive Sciences : An Interdisciplinary Approach Mayfield Publishing Company Mauntain View. - California, 2001. - $325 \mathrm{p}$.

5. Ciabattari Jane Workshop : A Revolution of Sensibility / Jane Ciabattari // Poets \& Writers Magazine. - Jan. / Feb, 2005. - Pp. 69-72.

6. Common European Framework of Reference for Languages : Learning, Teaching and Assessment. - Trim J. L. M. (Ed.). - Cambridge University Press, 2001. - 276 p.

7. Mayers Tim Writing Craft : Composition, Creative Writing, and the Future of English Studies / Tim Mayers. Pittsburgh : U of Pittsburgh Press, 2005.

8. Peter D. McClelland Readings in Introductory Macroeconomics [Text] : 1990-1991 Annual Edition / McClelland D. Peter. - New York ; St. Louis : McGraw-Hill, Inc., 1991. - 256 p.

9. Russell R. G. The Need to Teach Communication Strategies in the Foreign Language Classroom / R. G. Russell, L. Loschky // JALT Journal. - Volume 20, No. 1, 1998. - Pp. 34-45.

\section{Стєбаєва С. В. Комунікативний підхід у викладанні італійської мови як другої іноземної.}

Стаття присвячена теоретичному та методичному дослідженню специфіки викладання італійської мови як другої іноземної та підвищенню рівня професійної комунікативної компетентності на заняттях. Висвітлено перспективу використання комунікативного підходу, а також вимоги до його вибору. Зазначається, що невеликі діалоги є важливим ресурсом під час вивчення нових термінів і що, в цілому, вони підвищують рівень професійної комунікативної підготовки філологів.

Особливість сучасної комунікативної підготовки у викладанні італійської мови зумовлена інтеграційними процесами в нашому суспільстві, глобалізацією та доступом до інформації в усьому світі, необхідністю висококваліфікованих фахівців у галузі перекладу та туризму. Вимога нашого часу змінити підхід освітньої парадигми, надаючи пріоритет комунікативній підготовці, щуо вказує на

головну мету навчального процесу на рівні ВНЗ. Експериментально обтрунтована система комунікативного підходу у викладанні італійської мови, як другої іноземної, складається з трьох 
основних етапів: підготовки, основної частини та аналізу. Найважливішою частиною технологї $\epsilon$ формування імпринтингу в процесі вивчення нових слів і готовність писати творчі есе. Комунікативний підхід спрямований на формування іноземної комунікативної компетентності майбутніх філологів.

Ключові слова: комунікативний підхід, викладання італійської, друга іноземна мова, професійна комунікативна підготовка, майбутні філологи, творче письмо, комунікативна компетентність, комунікативна підготовка.

\section{Стебаева С. В. Коммуникативный подход в преподавании итальянского языка как второго иностранного.}

Статья посвящена теоретическому и методическому исследованию специфики преподавания итальянского языка как второго иностранного и повышению уровня профессиональной коммуникативной компетентности на занятиях. Освещается перспектива использования коммуникативного подхода, а также требования кего выбору. Отмечается, что небольшие диалоги являются важным ресурсом при изучении новых терминов и, в целом, они повышают уровень профессиональной коммуникативной подготовки филологов.

Особенность современной коммуникативной подготовки в преподавании английского языка обусловлена интеграционными процессами в нашем обществе, глобализацией и доступом к информации во всем мире, необходимостью высококвалифицированных специалистов в области перевода и туризма.

Требование нашего времени - изменить подход образовательной парадигмы, предоставляя приоритет коммуникативной подготовке, что указывает на главную цель учебного процесса на уровне ВУЗа. Экспериментально обоснованная система коммуникативного подхода в преподавании английского язика, как второго иностранного, состоит из трех основных этапов: подготовки, основной части и анализа. Важнейшей частью технологии является формирование импринтинга в прочессе изучения новых слов и готовность писать творческие эссе. Коммуникативный подход направлен на формирование иностранной коммуникативной компетентности будущих филологов.

Ключевые слова: коммуникативный подход, преподавание итальянского, второй иностранный язык, профессиональная коммуникативная подготовка, будущие филологи, творческое письмо, коммуникативная компетентность, коммуникативная подготовка. 